\title{
TREŚĆ VERSUS FORMA. Z ROZWAŻAŃ NAD NATURĄ TEKSTU LITERACKIEGO W ŚWIETLE UKRAIŃSKICH MANIFESTÓW LITERACKICH LAT 20. XX WIEKU
}

\author{
ALBERT NOWACKI \\ Katolicki Uniwersytet Lubelscki Jana Pawa II, Lublin — Polska \\ albert.nowacki@kul.pl; ORCID: 0000-0002-2418-0574 \\ ЗМICT VERSUS ФOРMA. \\ IЗ РОЗДУМІВ ПРО ПРИРОДУ ЛІТЕРАТУРНОГО ТЕКСТУ \\ В СВІТЛІ УКРАЇНСЬКИХ ЛІТЕРАТУРНИХ МАНІФЕСТІВ \\ 1920-X PP.
}

\author{
АЛЬБЕРТ НОВАЦЬКИЙ \\ Люблінський католицький університет Івана Павла II, Люблін - Польща
}

\begin{abstract}
АНОТАЦІЯ. Метою статті є рефлексія над цікавим питанням, яке виникло на зламі XIX та $\mathrm{XX}$ століть в ураїнській літературі, а саме - первинності змісту над формою чи форми над змістом. Автор статті підкреслює, що згадане питання було предметом роздумів та суперечок наприкінці XIX століття, коли модерністична література, шукаючи нових способів художнього вираження, надала перевагу формі літературного твору над його змістом. Модерністи почували себе звільненими від обов'язку “моралізувати та вчити” читача, стверджуючи, що обов'язок художника - постійно експериментувати з формою. Автор покликається на Миколу Вороного, Миколу Сріблянського, Якова Можейка, Дмитра Загула та середовища, пов'язані з журналами „Музагет”, „Літературно-науковий вісник”, „Українська хата”, а також із групою „Молода муза”. Дискусії зламу століть знову ожили у 1920-і рр. у новоствореній Українській Радянській Республіці. Прихильники соціалістичного реалізму стверджували, що зміст літературного твору важливіший, адже, на їхню думку, обов'язок письменника — “виховувати” суспільство. Спираючись на проведене дослідження, можна також констатувати, що були й письменники, які підкреслювали суттєве значення форми літературного твору. Серед них, між іншим, члени групи „Гроно”. У статті проаналізовано ідеї, висловлені Валеріаном Поліщуком, який запропонував концепцію літературного спіралізму (література як математика). Також згадується
\end{abstract}


цікава теорія вірша, де на перший план письменник висував евфонію. Це була його авторська концепція нового ритму вірша, відомого як “хвиляда”.

Ключові слова: українська література, дискусія, форма та зміст, письменник,експеримент, концепція.

\title{
CONTENT VERSUS FORM. FROM THE CONSIDERATIONS ON THE NATURE OF THE LITERARY TEXT IN THE LIGHT OF THE UKRAINIAN LITERARY MANIFESTOES OF THE 1920S
}

\author{
ALBERT NOWACKI \\ The John Paul II Catholic University of Lublin, Lublin — Poland
}

\begin{abstract}
The purpose of this paper is to reflect on an extremely interesting issue, which was the attempt to explain the primacy of content over form or form over content in Ukrainian literature. The author emphasizes that this issue was the subject of considerations at the end of the 19th century, when modernist literature, looking for new ways of artistic expression, gave primacy to the form of a literary work over its content. Modernists felt freed from the duty of "moralizing" the reader, arguing that the writer's duty is to constantly experiment with the form. The author refers to such figures as Mykola Voronyj, Mykola Sriblanski, Yakiv Mozhejko, Dmytro Zahul, and circles associated with the magazine "Muzahet", "Literature Critical Almanac", "Ukraïns'ka khata" and the literary group "Moloda Muza". Discussions at the turn of the century came alive again in the 1920s in the newly formed Ukrainian Soviet Republic. Supporters of socialist realism argued that the content of the literary work is more important, because, in their opinion, the writer's duty is to "educate" society. Based on the research conducted, it can also be stated that at the same time there were also writers who emphasized the significant importance of the form of the literary work. Among them were members of the literary group called "Grono". Later in the paper, the ideas advanced by Valeriian Polishchuk, who proposed the concept of the literature of the spiral (literature like mathematics ), are analysed. An interesting poem theory is also mentioned here, where euphony came to the fore. It was the author's concept of a new rhythm of the poem, referred to as the "khvilyada".
\end{abstract}

Keywords: Ukrainian literature, discussion, form and content, writer, experiment, concept.

J ednym z najciekawszych etapów w historii rozwoju nowożytnej literatury ukraińskiej jest bez wątpienia literatura lat 20. ubiegłego wieku. Był to czas interesujących eksperymentów literackich i nieustannych poszukiwań nowych form estetycznych. Powstająca naówczas literatura nie tylko odzwierciedlała zmiany paradygmatów kulturowych, ale świadczyła wymownie o szerokiej gamie zainteresowań ukraińskich twórców nowymi rodzajami form wyrazu literackiego. Zmęczonym latami I wojny światowej, a potem wewnętrznymi walkami o władzę obywatelom nowo powstałego Związku Radzieckiego, a w szczególności Ukrainy 
Radzieckiej mogło się wydawać, że nowa rzeczywistość przyniesie wytchnienie i nareszcie pozwoli na zajęcie się sprawami kultury, które w obliczu wojennej zawieruchy zazwyczaj schodziły na dalszy plan.

Na początku lat 20. Ukraińcy, którzy znaleźli się pod władzą bolszewików, mogli odnieść wrażenie, że obserwowane zmiany społeczno-polityczne przyniosą niemal nieograniczone możliwości rozwoju rodzimej kultury, bowiem chyba po raz pierwszy w historii ukraińska kultura znalazła się formalnie pod opieką państwa [Nowacki 2013: 22-23]. Wrażenie to pogłębiały liczne deklaracje partyjnych decydentów mówiące o tym, że w procesie instalacji nowego państwa właśnie kultura oraz literatura będą odgrywać jedną z najważniejszych ról, albowiem marksistowska myśl estetyczna zakładała wykorzystanie tychże narzędzi do tworzenia nowej mitologii i kreowania zupełnie innej rzeczywistości [Лейтес, Яшек 1928: 289-292]. Jak podkreśla Stefan Morawski, powinnością twórczości w duchu komunistycznym „miało być nie odbijanie świata, ale współtworzenie go - analogicznie do roboty konstruktorskiej, inżynierskiej, fabrycznej" [Morawski 2000: 135]. W świetle powyższej konstatacji do najcenniejszej twórczości miała być zaliczana literatura faktu, a także film dokumentalny, plakaty oraz różnego rodzaju agitki.

Niemalże od samego początku lat 20. pojawiły się dyskusje na temat kształtu nowej literatury ukraińskiej, jej form, funkcji, a także estetyki. Na przestrzeni nieomal całego trzeciego dziesięciolecia XX wieku ukraińską areną literacką wstrząsały liczne dysputy pomiędzy zwolennikami „,partyjnej linii” w literaturze oraz propagatorami czerpania z nowoczesnych wzorców zachodnich. Jurj Łuckyj podliczył, że w owych debatach głos zabierały setki uczestników, a ich owocem było ponad tysiąc broszur, artykułów, pamfletów i innych tekstów [Луцький 2000: 70], co tym dobitniej świadczy o intensywności toczonych sporów. Wśród tematów wywołujących największe emocje była z pewnością kwestia orientacji literatury ukraińskiej - na Wschód czy na Zachód, dominująca estetyka, a także rola i zadania twórcy oraz forma i kształt dzieła literackiego, jak również prymat treści nad formą (lub odwrotnie). Właśnie temu ostatniemu zagadnieniu przyjrzymy się uważniej w dalszej części niniejszego artykułu.

Doświadczenia modernizmu ukraińskiego uświadomiły wielu pisarzom, że zarówno kwestia wyjaśnienia roli twórcy, jak też i sama forma dzieła literackiego to problemy, które należy rozwiązać niezwłocznie. Wspomniane zagadnienia podnosili wielokrotnie m.in. Łesia Ukrainka, Iwan Franko czy Mykoła Worony [Nowacki 2017: 481-493], który w opublikowanym w 1901 roku apelu nawoływał kolegów po piórze, by do przygotowywanego przez niego nowego zbiorku literackiego nadsyłali takie utwory, które ,[...] змістом і виглядом бодай почасти міг наблизитись до новійших течій та напрямків в сучасних літературах европейських" [Вороний 1901: 14]. Z czasem do tego grona dołączył także Mykoła Sriblanski (czyli Mykyta Szapował), który podkreślał, iż ważne nie jest to, о czym się pisze, ale to, jak się pisze [Сріблянський 1910: 489-499], a najważ- 
niejsza wcale nie jest sama literatura, będąca rezultatem końcowym, lecz twórczość, w której na pierwsze miejsce wysuwa się wyjątkowa twórcza jednostka.

Modernistyczne zwrócenie się ku formie dzieła literackiego było, jak się wydaje, swoistą reakcją na obecną jeszcze u schyłku XIX wieku manierę pozytywistyczną, która jak się wyraził Jurij Kowaliw, niosła ze sobą pewne ograniczenia starej szkoły kulturalno-historycznej [Ковалів 2014: 44], jak również na utylitarystyczną ideologię narodnictwa. W rezultacie na ukraińskim gruncie literackim pojawiły się próby implementacji założeń formalizmu, które notabene miały miejsce równolegle do analogicznych poszukiwań rosyjskiej szkoły formalnej, jednakże w ostatecznym rozrachunku nie znalazły one wystarczającego uznania wśród ukraińskich pisarzy i krytyków literackich. Wspomina o tym także Wira Ahejewa, która przestrzega, że nie warto wyolbrzymiać wpływu rosyjskich formalistów na przedstawicieli ukraińskiego środowiska literackiego [Агеєва 2016: 25]. Dokonania członków OPOJAZ-u oraz prace rosyjskich symbolistów z Andriejem Biełym na czele sprawiły jednak, że również na gruncie ukraińskim zainteresowano się problematyką związaną z formą dzieła literackiego, w czym celowały przede wszystkim środowiska skupione wokół czasopisma „Muzahet” („Музагет”, 1918) i „Literaturno-krytycznyj almanach” (,Літературно-критичний альманах”, 1918) oraz rolą pisarza w procesie literackim i jego odpowiedzialnością wobec odbiorcy.

Wspomniany „Almanach” był ciekawą próbą stworzenia pisma artystycznego, które miałoby pełnić rolę swoistej platformy prezentującej zarówno nowe szkoły krytyki literackiej, jak też i nowych twórców. Choć sami założyciele pisma nigdzie o tym nie wspominają, to jak twierdzi Sołomija Pawłyczko ich prawdziwą intencją było podjęcie próby stworzenia nowej krytyki literackiej, która nie angażując się ideologicznie czy światopoglądowo, skupiałaby się na tym, w jaki sposób powstawał utwór literacki, a zwłaszcza utwór poetycki [Павличко 1999: 179-180]. Redaktorzy nie oferowali gotowego przepisu na twórczość literacką, choć umieszczone tu teksty Jakowa Możejki, Jakowa Sawczenki, czy Dmytra Zahuła świadczyły, że takowe próby są podejmowane. W tym kontekście warto zwrócić uwagę na piszącego pod pseudonimem Iwana Majdana Dmytra Zahuła, który wprawdzie wyrażał swą radość z ukraińskiego odrodzenia narodowego oraz z tego, że bierze w nim udział tak wielu adeptów pióra, apelował jednak o powstrzymanie się od tworzenia sztuki zaangażowanej ideologicznie, albowiem, jak pisał, „поет при тому мусить пам'ятати одно, а саме, що він зачарований красою відродження, а не своїм народом. Зрозуміло, що в цей час великого відродження нашого народу багато наших «корифеїв» пішло на послуги тому відродженню і тим тратять під собою грунт мистецтва чистого, самоцільного, - стають більше патріотами, як поетами. Для загалу це «благо», для самих поетів упадок, застій” [Майдан 1918: 25].

Uwagę zwracają także zamieszczone w „Almanachu” artykuły krytyczne, w których, inaczej niż do tej pory, niemal nie poświęcono żadnej uwagi tematy- 
ce analizowanych utworów. Zamiast tego krytycy skupili się na analizie strony formalnej dzieła literackiego, zamieszczając rozległe analizy obrazowania poetyckiego, metryki, rytmu czy sposobów tworzenia rymów ${ }^{1}$. Podobną tendencję zaprezentowali również redaktorzy pisma „Muzahet”, zamieszczając tu pracę Jurija Iwaniwa-Meżenki na temat poezji Pawła Tyczyny, a dokładnie — tomiku Słoneczne klarnety (Соняшні кларнети, 1918). Także i tutaj, zamiast analizować treść wierszy Tyczyny, autor skupił się raczej na analizie warstwy dźwiękowej utworów [Меженко 1919: 126-128], a następnie przyjrzał się stronie formalnej oraz zastosowanym przez Tyczynę sposobom obrazowania poetyckiego.

Środowisko skupione wokół „Muzahetu” wysłało jasny sygnał, że aby literatura ukraińska mogła wyrwać się z impasu spowodowanego długotrwałym wpływem ideologii narodnickiej, musi porzucić myśli o ideologicznym zaangażowaniu twórcy i jego powinnościach względem narodu na rzecz całkowitej wolności twórczej i tworzenia sztuki dla niej samej. Wspominał o tym Jurij Meżenko w błyskotliwym artykule Twórczość jednostki i kolektyw, pisząc: „Я кажу про аксіому, яка стверджує те, що творчий індивідуум тільки тоді може творити, коли визнає себе вищою істотою понад загал і коли, не підлягаючи загалові, все ж таки почуває свою з ним спорідненість" [Іванів-Меженко 1919]. Wypowiedź Meżenki doskonale korespondowała z przedstawicielami „Ukraińskiej Chaty” czy „Młodej Muzy” [Matusiak 2006: 16-17], którzy również skłaniali się ku temu, że prawdziwą sztukę może uprawiać tylko jednostka wolna, nieskrępowana żadnymi powinnościami wobec społeczeństwa.

Głos w sprawie estetyki nowej literatury ukraińskiej zabrali także pisarze-awangardyści, którzy również nie uznawali krępujących norm powinności obywatelskich. W 1920 roku pojawił się manifest ugrupowania literackiego "Grono", w którym autorzy przedstawiali swoją własną wizję literatury. Twierdzili mianowicie, że perspektywiczna jest tylko synteza istniejących już prądów artystycznych, wśród których wyodrębniali impresjonizm oraz futuryzm. W ten oto sposób, jak podkreśla Agnieszka Korniejenko, „Grono chciało znaleźć kompromis i pośrednie wyjście pomiędzy skrajnościami: subiektywnym i idealistycznym symbolizmem a pragmatyczną sztuką kolektywu" [Korniejenko 1998: 129].

W swoim manifeście członkowie grupy podkreślali, że „лишень одвіявши плевела від різних течій і привівши їх до гармонійної синтези, новоутворена мистецька форма буде задовольняти широкий загал людства. Тоді мистецтво виконає те велике завдання, яке на нього поклала природа" [Лейтес, Яшек 1928: 30].

Jednym z członków „Grona” był także Walerian Poliszczuk, który starał się zaproponować swoją własną koncepcję sztuki oraz formy dzieła literackiego. Należy

\footnotetext{
${ }^{1}$ Zob. I. Майдан, Шукання, ор. cit., Я. Савченко, Михайло Семенко. „П'єро задається”, [в:] „Літературно-критичний альманах”, Київ 1918, с. 28-45; Я. Можейко, Творчість Чупринки (критичний нарис), [в:] „Літературно-критичний альманах”, Київ 1918, с. 46-65.
} 
zacząć od tego, że w kilku swoich pracach teoretycznych zaproponował on garść interesujących koncepcji, których nie sposób pominąć milczeniem.

Dla wielu współczesnych historyków literatury ukraińskiej Poliszczuk nie jest postacią jednoznaczną: jedni widzą w nim nieledwie dyktatora, który chciałby zunifikować literaturę ukraińską i nieomal siłą zmuszać innych twórców, by przyjmowali jego punkt widzenia [рor. Ковалів 1998: 152-154], inni zaś wskazują, że pisarz dążył do podkreślenia znaczenia twórczego ,ja” i przeciwstawiał się dogmatyce twórczości kolektywnej rodem z Proletkultu [Жулинський 2002: 361-375]. Podobnie niejednoznacznie oceniali go także współcześni, którzy z jednej strony widzieli w nim „Homera rewolucji”, dla innych zaś, jak chociażby dla Mykoły Chwylowego, był tylko „skisłym pseudokonstruktywistą” i „,achtanabilem współczesności”. Nie ulega jednak wątpliwości, że jego teorie zostały przez współczesnych dostrzeżone, a nawet wywołały polemikę na łamach prasy.

„Wczesny” Poliszczuk skłaniał się raczej w kierunku tzw. neorealizmu proletariackiego z elementami neoromantycznymi. Jego poetycka twórczość tego okresu poruszała zagadnienia związane z niedawno przebrzmiałą rewolucją (kosmos rewolucyjny, tragedia wojny domowej itp.), choć zdarzały się skomplikowane utwory wynikające z fascynacji balladą, filozofią i innymi tekstami literatury, przy czym większość z nich powstała jako vers libre. W 1921 roku zwrócił się w kierunku dynamizmu, a w połowie lat 20. zainteresował się nurtem konstruktywizmu, choć jak zauważał Jurij Kowaliw, w porównaniu z konstruktywistami niemieckimi czy rosyjskimi jego teorie były mniej racjonalne [Ковалів 1998: 153]. W tym czasie zaczynały się formować jego poglądy odnośnie do funkcji i kształtu dzieła literackiego, które zdecydował się przekazać w kilku swoich pracach.

Koncepcja „dynamicznego konstruktywizmu” Waleriana Poliszczuka, na którą składały się „urbanizm, industrializacja i vers libre” z czasem ewoluowała w koncepcję spiralizmu. Jak wyjaśniał sam autor, proces historycznoliteracki ma charakter spirali i rozwija się zgodnie z logiką dynamicznej konstrukcji matematycznej. Jak pisał, „спіралізм, як мистецько-філософський термін, випливає з таких положень: як поступування життя, так і розвиток мистецьких форм іде спіраллю. Діалектика життя, беручи для даного моменту певну вихідну точку, веде відповідними витками поступ. Ці витки творяться внаслідок одштовхувань од попереднього стану. Вони (витки і повороти), пройшовши етап цілковитого (діаметрального) заперечення, доходять знов до аналогічного з попереднім пунктом положення, де вже синтезуються начала обох попередніх фраз, але й, головне, додається ще й нове щось, небувале у попередніх етапах" [Поліщук 1997: 24]. W tym miejscu wypada zgodzić się z Anną Biłą, która zauważyła, że koncepcja spiralizmu Poliszczuka nosi znamiona inspiracji ideami panfuturyzmu Mychajla Semenki oraz witaizmu Mykoły Chwylowego [Біла 2006: 228], jest bowiem próbą syntezy Wschodu i Zachodu, tendencji industrializacyjnych, a za główne narzędzie twórczości obiera poezję. 
Walerian Poliszczuk jest także autorem interesującej teorii poezji dynamicznej. W celu wprowadzenia odbiorców w sens własnej koncepcji twórca zaproponował autorski podział literatury ukraińskiej na trzy okresy, wśród których wyodrębniał czas, gdy literatura ukraińska skupiała się na ukraińskich wartościach (wskazywał tutaj takie postacie w historii literatury, jak Iwan Kotlarewski, Hryhorij Kwitka-Osnowianenko czy Marko Wowczok), okres świadomości kulturalno-narodowej, w którym nastąpiło „uświadomienie”, że Ukraińcy to w rzeczywistości naród wiejski, i ostatni okres, kiedy uświadomiono sobie, że „u nas może być tak, jak na Zachodzie" (Łesia Ukrainka, Mychajło Kociubynski, Mykoła Worony, Mychaj1 Semenko) [Поліщук 1926: 5-6]. Twierdził ponadto, że po rewolucji przyszedł czas na czwarty okres, w którym Ukraińcy nie tylko wiedzą, co i jak należy brać z Zachodu i - częściowo — ze Wschodu, ale mają już coś swojego, są tego świadomi, mało tego, sami mogą już wnosić wkład do światowej literatury [Поліщук 1926: 6]. Znamienny jest fakt, że w swojej periodyzacji zupełnie pominął on dorobek koryfeuszy literatury ukraińskiej, w tym największego z nich - Tarasa Szewczenki, chociaż z drugiej strony wybiórcze traktowanie tradycji literackiej było dość charakterystyczne dla awangardystów, którzy nierzadko widzieli się w roli destruktorów tradycji [zob. Павличко 1999: 186].

Poliszczuk uważał, że czwarty etap rozwoju literatury ukraińskiej będzie obfitował w utwory o tematyce ,mechanicznej”, które zostaną skierowane do robotników, czyli ukraińskiego proletariatu. Aby jednak dotrzeć do właściwego odbiorcy, pisarz był przekonany, że w tym celu niezbędna jest dynamizacja sztuki. Miała ona polegać na tym, że „для передачі почування від творця до людей приймаючих, виявляється мистецькими засобами духовне напруження в експресивній формі рітму евфонії, образів, сюжету та ідей, маючи завданням дати гармонійний сінтез усіх творчих засобів, техничних здобутків та наукового знання" [Поліщук 1926: 13]. Awangardysta uważał, że najskuteczniejszym sposobem na dynamizowanie poezji jest tworzenie dysonansów dźwiękowych na podobieństwo muzyki (przywoływał tu postać rosyjskiego pianisty eksperymentatora Aleksandra Skriabina) oraz stosowanie epitetów i metafor ruchu, które dają odbiorcy wrażenie trójwymiarowości [Поліщук 1926: 15].

Zamiarem Poliszczuka była destrukcja dotychczasowej ukraińskiej tradycji poetyckiej, która, jego zdaniem, opierała się na przestarzałym rytmie kołomyjkowym. Nie podobały mu się także dokonania współczesnych kolegów po fachu, w tym „neoklasyków” i Mykoły Chwylowego. Jak pisał, „дуже помиляються такі письменники на Вкраїні, як хвильові й зерови, що животіння «сонетистів» та «александрійців» (вірних сторонників класичного александрійського віршу) вважають за передовий рух, за яким начебто майбутнє, а не епігонами, як би слід, минулої доби парнасців та сімволістів, з традиціями їхньої лексіки. По нашому ці «європейці» — назадники [...]” [Поліщук 1926: 81]. Wychodząc z powyższego, pisarz stwierdzał, że najlepszym rozwiązaniem, które z pewnością 
unowocześni poezję ukraińską, jest zastosowanie wiersza wolnego, dodatkowo wzbogaconego o leksykę urbanistyczno-industrialną, gdyż tylko taka konstrukcja odpowiada epoce szybkiej industrializacji w Ukrainie [Поліщук 1926: 86].

Poliszczuk podkreślał, że obraz jest dla poezji drugoplanowy, na pierwszy plan bowiem wysuwają się elementy dźwiękowe, czyli eufonia, która nadaje poezji właściwe znaczenie [Поліщук 1926: 90]. Jak powszechnie wiadomo, język stanowi system znaków dźwiękowych, stąd też owo dźwiękowe tworzywo języka można poddawać różnorakim zabiegom pozwalającym na jego estetyczne waloryzowanie. $\mathrm{O}$ ile w tekstach niepoetyckich wartość foniczna języka nie ma większego znaczenia, o tyle sytuacja zmienia się w przypadku tekstów o charakterze poetyckim, gdzie niejednokrotnie zachodzi konieczność wyeksponowania materiału językowego. Jak zauważa Adam Kulawik, „dążność do wydobywania walorów estetycznych tej warstwy tekstu może przybrać zróżnicowane postaci, może przejawić się w zróżnicowanych zabiegach stylistycznych, które stylistyka rozmaicie ponazywała, ale ma również dla nich jedną wspólną nazwę - eufonia. [...] Jest to zatem nazwa zbiorcza dla wszystkich typów organizacji naddanej tekstu w jego warstwie brzmieniowej, które w jakimś okresie uważane są za estetycznie dodatnie" [Kulawik 1997: 57]. Podobna konstatacja stanowiła z pewnością punkt wyjścia dla dalszych rozważań Waleriana Poliszczuka. Przyjmował on mianowicie, że poezja to tak na prawdę „system szumów”, na który składają się dysonanse i asonanse: ,[... ] поезія, коли вже обов’язково її прирівнювати до сучасної музики, належить швидше до музики шумів, а не музики тонів" [Поліщук 1926: 92].

Jak już wspomniano, Walerian Poliszczuk uznał, iż dynamiczną współczesność najlepiej reprezentować będzie wiersz wolny, a skoro ówczesna poetyka, jego zdaniem, nie do końca radziła sobie z utworami tego typu, zaproponował autorską teorię wierszowania. Myliłby się jednak ten, kto oczekiwałby jakiejś uporządkowanej frazy intonacyjnej, stopy rytmicznej czy metru [por. Mayenowa 2000: 381-387]. Zamiast tego awangardzista wprowadza autorski termin „chwylada”, który opiera się na zasadzie podobieństwa do fali morskiej: „Ритм складається з ріжноманітних одрізків наповненого звуками часу, що можуть бути освідомлені, як повторення груп звуків. Ті одрізки часу, наповненого звуками слів, ідуть хвилями, що не завше можуть бути зрівняні між собою і в більшости сприймаються як ірраціональні величини, з ріжним евфоничним забарвленням, але 3 якимсь середнім математичним, до якого наближаються ті величини, і через те людська психіка сприймає їх як величини одного порядку, як наприклад морські хвилі з ріжною формою поверхні, гребінів, розмаху i т. ин. Ці ритмичні одиниці ми називаємо хвилядами. Вони розділяються поміж собою ірраціональними уривками незаповненого вільного, але напруженого часу 一 павзниками і павзами. В кожній хвиляді повинно бути по одному i більше наголосів, при чім в останніх випадках завше $є$ один домінуючий наголос, що емоціонально зафарблює цілу хвиляду” [Поліщук 1926: 97-98]. 
Wyjaśnienia systemu chwylad zamieszczone przez samego autora nie sprawiają, że staje się on jasny i czytelny, wręcz na odwrót - dostarczają wielu problemów interpretacyjnych. Na podstawie zamieszczonych w analizowanym tekście przykładów można stwierdzić, że Poliszczukowi nie chodziło o jakiś logiczny podział tekstu na jednostki podporządkowane akcentowi głównemu, bo jak zauważa Agnieszka Korniejenko „warstwa eufoniczno-słuchowa musi odpowiadać napięciu semantycznemu w utworze" [Korniejenko 1998: 134]. Wspomniana przez autora „średnia matematyczna" miała oznaczać po prostu stały rytm, który podczas deklamowania wiersza można byłoby cicho wystukiwać nogą, co dawałoby wierszowi wolnemu pozory regularności.

Przytaczane przez Poliszczuka przykłady konkretnych utworów, na które „nałożono" system chwylad, mogą świadczyć, iż ich stosowanie pozostawiało sporo dowolności. Owa tolerancja pozwalała deklamującemu na subiektywne interpretowanie elementów już w obrębie jednego wiersza, co z kolei mogło decydować o tym, że dany utwór, a nawet jego poszczególne fragmenty, mogły zmieniać znaczenie zależnie od sposobu deklamacji / odczytania.

Należy przyznać, że w swoich manifestach Walerian Poliszczuk okazywał niekonsekwencję. Jurij Kowaliw zauważył, że jego fascynacja wierszem wolnym zdradzała pragnienie bycia liderem, tym, który lansuje określone trendy [Ковалів 2014: 108]. Ową niekonsekwencję dość szybko wytknął mu Mykoła Chwylowy, który w jednym ze swoich pamfletów poddał teorie awangardysty druzgocącej krytyce [Хвильовий 1938: 203-232], ironizując, że Poliszczuk nie pisze vers librem, lecz zwykłą prozą [Хвильовий 1938: 224]. Pomimo tego, że jego teorie nie zyskały zbyt wielu zwolenników, należy przyjąć, iż były nader ciekawe i intrygujące, i z całą pewnością stanowiły zauważalny wkład do dyskusji o tym, co ważniejsze: treść czy forma?

Można powiedzieć, że dyskusje o prymacie formy nad treścią lub odwrotnie trwały aż do końca lat 20. Niemal od razu wyodrębniły się dwa obozy: bardziej świadomi swego rzemiosła pisarze przekonywali, że większą uwagą należy obdarzyć formę dzieła literackiego, albowiem dostosowanie się do wymogów formalnych wymaga od twórcy nie tylko talentu, ale także odpowiedniej wiedzy. Poza tym zadaniem sztuki nie jest wychowywanie społeczeństwa, lecz kształtowanie jego gustów estetycznych. Inna grupa pisarzy była skłonna twierdzić, że od formy ważniejsza jest treść dzieła literackiego, bo dzięki niej można wychowywać społeczeństwo i kształtować je w pożądanym kierunku. Taka postawa doskonale odpowiadała linii partyjnej w literaturze, o której już na początku niniejszego artykułu powiedzieliśmy, że zadaniem jej jest kształtowanie obywatela w duchu komunizmu.

Tytułem podsumowania należy stwierdzić, że pod koniec lat 20. kwestii „treść czy forma?" nie rozwiązano w wyniku dyskusji na argumenty, została bowiem dość brutalnie ucięta już na początku lat 30., kiedy bolszewicy postanowili zlikwidować wszelkie przejawy pluralizmu w literaturze i autorytatywnie ogłosili prymat treści w duchu realizmu socjalistycznego nad „burżuazyjną” formą dzieła literackiego. 


\section{Wykaz wykorzystanej literatury}

Korniejenko A., Ukraiński modernizm. Próba periodyzacji procesu historycznoliterackiego, Kraków 1998.

Kulawik A., Poetyka. Wstęp do teorii dzieła literackiego, Kraków 1997.

Matusiak A., W kręgu secesji ukraińskiej. Wybrane problemy poetyki twórczości pisarzy „Młodej Muzy”, Wrocław 2006.

Nowacki A., „,Myśli pod prąd”. Twórczość Mykoły Chwylowego w kontekście ukraińskiej dyskusji literackiej lat 1925-1928, Lublin 2013.

Nowacki A., Manifesty u początków modernizmu ukraińskiego (,List otwarty do pisarzy ukraińskich” Mykoty Woronego), [w:] „Slavia Orientalis”, 2017, nr 3, t. LXVI, s. 481-493.

Mayenowa M.R., Poetyka teoretyczna. Zagadnienia języka, Wrocław - Warszawa - Kraków 2000.

Morawski S., O marksistowskiej myśli estetycznej, [w:] Estetyki filozoficzne XX wieku, red. K. Wilkoszewska, Kraków 2000, s. 133-158.

Біла А., Украӥнський літературний авангард: пошуки, стильові напрямки, Київ 2006.

Вороний М., „Відкритий лист”, [в:] „Літературно-науковий вістник”, 1901, кн. IX, с. 14. Десять років української літератури (1917-1927), т. II: Організаційні та ідеологічні иляхи української радянської літератури, Харків 1928, с. 289-292.

Жулинський М., Валер'ян Поліщук, [в:] Слово і доля, Київ 2002, с. 361-375.

Іванів-Меженко Ю., Творчість індивідуума і колектив, [в:] „Музагет”, 1919, № 1/3, с. 9-47. Ковалів Ю., Валер'ян Полішук, [в:] Історія української літератури ХХ століття, ред. В. Дончик, т. 1, Київ 1998, с. 297-301.

Ковалів Ю., Історія украӥнської літератури. Кінець XIX-nоч. XXI cm., т. 3: У сподіваннях і трагічних зламах, Київ 2014.

Луцький Ю., Літературна політика в радянській Україні 1917-1934, Київ 2000.

Майдан I., Шукання, [в:] „Літературно-критичний альманах”, Київ 1918, кн. 1, с. 23.

Меженко (Іванов) Ю., П. Тичина. „Соняшні кларнети”, [в:] „Музагет”, 1919, № 1/3, c. $125-134$.

Можейко Я., Творчість Чупринки (критичний нарис), [в:] „Літературно-критичний альманах", Київ 1918, с. 46-65.

Павличко С., Дискурс модернізму в українській літературі, Київ 1999.

Поліщук В., Верлібр і його соиіальна основа, [в:], Літературний авангард. Перспективи розвитку української культури, полеміка і теорія поезї, Харків 1926, с. 83-88.

Поліщук В., Завдання доби, [в:] Літературний авангард. Перспективи розвитку української культури, полеміка і теорія поезї, Харків 1926, с. 5-20.

Поліщук В., Здвиги й розвиток поетичної мови та сучасність, [в:] Літературний авангард. Перспективи розвитку украӥнської культури, полеміка і теорія поезї, Харків 1926, с. 73-82.

Поліщук В., Ритм новітньої поезії та його українські особливости (Схематичний начерк з теорії нової поезії), [в:] Літературний авангард. Перспективи розвитку української культури, полеміка і теорія поезії, Харків 1926, с. 89-131.

Поліщук В., Коли жити - гордо жити! Літературна спадщина. Спогади про В. Поліщука. У вінок поету, упорядк. З. Суходуб, Рівне 1997. 
Лейтес А., Яшек М., Десять років української літератури (1917-1927), т. II: Організаиійні та ідеологічні шляхи украӥнської радянської літератури, Харків 1928.

Савченко Я., Михайло Семенко. „П'єро задається”, [в:] „Літературно-критичний альманах", Київ 1918, с. 28-45.

Сріблянський М., ,,Нове слово” в українській критиці, [в:] „Українська хата”, 1910, № 7-8, c. 489-499.

Хвильовий М., „Ахтанабіль” сучасності, або Валеріян Полішук у ролі лектора комуністичного університету, [в:] Хвильовий М., Твори в n'ятьох томах, т. IV, Нью-Йорк Балтимор - Торонто 1938, с. 203-232.

\section{Wykaz wykorzystanej literatury [References]}

Korniejenko A., Ukraiński modernizm. Próba periodyzacji procesu historycznoliterackiego [Ukrainian Modernism. Attempts to Periodise the Historical and Literary Proces], Kraków 1998.

Kulawik A., Poetyka. Wstęp do teorii dzieła literackiego [Poetics. Introduction for a Theory of a Literary Work], Kraków 1997.

Matusiak A., W kręgu secesji ukraińskiej. Wybrane problemy poetyki twórczości pisarzy „Młodej Muzy" [In a Circle of Ukrainian Secession. Selected Issues of Writers' Ouvre in Poetics], Wrocław 2006.

Nowacki A., „,Myśli pod prąd”. Twórczość Mykoły Chwylowego w kontekście ukraińskiej dyskusji literackiej lat 1925-1928 [,, Upstream Thoughts”. Mykola Khvylovyi's Ouvre Against Literary Discussions in Ukraine between 1925 and 1928], Lublin 2013.

Nowacki A., Manifesty u początków modernizmu ukraińskiego („List otwarty do pisarzy ukraińskich” Mykoty Woronego) [Manifests at the Beginning of Ukrainian Modernism (Mykola Voronyi 's ,Open Letter to Ukrainian Writers”)], [w:] „Slavia Orientalis”, 2017, nr 3, t. LXVI, s. 481-493.

Mayenowa M.R., Poetyka teoretyczna. Zagadnienia języka [Theoretical Poetics. Questions of a Language], Wrocław - Warszawa - Kraków 2000.

Morawski S., O marksistowskiej myśli estetycznej [About a Marxist Esthetical Thought], [w:] Estetyki filozoficzne XX wieku, red. K. Wilkoszewska, Kraków 2000, s. 133-158.

Bila A., Ukrainskyi literaturnyi avanhard: poshuky, stylovi napriamky [Ukrainian Literary Cutting Edge: Searches and Style's Lines of Action], Kyiv 2006.

Voronyi M., ,Vidkrytyi lyst” [An Open Letter], [v:] „Literaturno-naukovyi vistnyk”, 1901, kn. IX, s. 14.

Desiat rokiv ukrainskoi literatury (1917-1927) [Ten Years of Ukrainian Literature (1917-1927)],

t. II: Orhanizatsiini ta ideolohichni shliakhy ukrainskoi radianskoi literatury, Kharkiv 1928, s. 289-292.

Zhulynskyi M., Valerian Polishchuk [Valerian Polishchuk], [v:] Slovo i dolia, Kyiv 2002, s. $361-375$. 
Ivaniv-Mezhenko Yu., Tvorchist indyviduuma i kolektyv [One Character's Ouvre and His Group], [v:] „Muzaget”, 1919, № 1/3, s. 9-47.

Kovaliv Yu., Valerian Polishchuk [Valerian Polishchuk], [v:] Istoriia ukrainskoi literatury XX stolittia, red. V. Donchyk, t. 1, Kyiv 1998, s. 297-301.

Kovaliv Yu., Istoriia ukrainskoi literatury. Kinets XX-poch. XXI st., t. 3: U spodivanniakh $i$ trahichnykh zlamakh [History of Ukrainian Literature. The End of 19 Century - the Beginning of 21 Century], Kyiv 2014.

Lutskyi Yu., Literaturna polityka v radianskii Ukraini 1917-1934 [Literary Politics in Soviet Ukraine, 1917-1934], Kyiv 2000.

Maidan I., Shukannia [Searches], [v:] „Literaturno-krytychnyi almanakh”, Kyiv 1918, kn. 1, s. 23.

Mezhenko (Ivanov) Yu., P. Tychyna. „, Soniashni klarnety” [P. Tychyna. ,, Sunny clarinets”], [v:] „Muzahet”, 1919, № 1/3, s. 125-134.

Mozheiko Ya., Tvorchist Chuprynky (krytychnyi narys) [Chuprynka's Ouvre (the Censourious Essay)], [v:] „Literaturno-krytychnyi almanakh”, Kyiv 1918, s. 46-65.

Pavlychko C., Dyskurs modernizmu v ukrainskii literaturi [Discussions about Modernism in Ukrainian Literature], Kyiv 1999.

Polishchuk V., Verlibr i yoho sotsialna osnova [Free Verse and Its Social Base], [v:], Literaturnyi avanhard. Perspektyvy rozvytku ukrainskoi kultury, polemika i teoriia poezii, Kharkiv 1926, s. 83-88.

Polishchuk V., Zavdannia doby [Tasks of the Epoch], [v:] Literaturnyi avanhard. Perspektyvy rozvytku ukrainskoi kultury, polemika i teoriia poezii, Kharkiv 1926, s. 5-20.

Polishchuk V., Zdvyhy y rozvytok poetychnoi movy ta suchasnist [Challenges and Development of the Poetical Language and Contemporaneity], [v:] Literaturnyi avanhard. Perspektyvy rozvytku ukrainskoi kultury, polemika i teoriia poezii, Kharkiv 1926, s. 73-82.

Polishchuk V., Rytm novitnoi poezii ta yoho ukrainski osoblyvosty (Skhematychnyi nacherk $z$ teorii novoi poezii) [A Rhythm of the Modern Poetry and Its Ukrainian Properties (A Schematic Essay on the Theory of Novel Poetry)], [v:] Literaturnyi avanhard. Perspektyvy rozvytku ukrainskoi kultury, polemika i teoriia poezii, Kharkiv 1926, s. 89-131.

Polishchuk V., Koly zhyty — hordo zhyty! [If You Do Live — Do It Proudly!], [v:] Literaturna spadshchyna. Spohady pro V. Polishchuka. U vinok poetu, uporiadk. Z. Sukhodub, Rivne 1997.

Leites A., Yashek M., Desiat rokiv ukrainskoi literatury (1917-1927) [Ten Years of Ukrainian Literature (1917-1927)], t. II: Orhanizatsiini ta ideolohichni shliakhy ukrainskoi radianskoi literatury, Kharkiv 1928.

Savchenko Ya., Mykhailo Semenko. „Piero zadaietsia” [Mykhailo Semenko. „Pierro Humiliates”], [v:] „Literaturno-krytychnyi almanakh”, Kyiv 1918, s. 28-45.

Criblianskyi M., ,, Nove slovo” v ukrainskii krytytsi [,, A New Word” in Ukrainian Critics], [v:] „Ukrainska khata”, 1910, № 7-8, s. 489-499.

Khvylovyi M., „Akhtanabil” suchasnosti, abo Valeriian Polishchuk u roli lektora komunistychnoho universytetu [,,Akhtanabil” Modernity, or Valerian Polishchuk as a Lecturer at a Communist University], [v:] Khvylovyi M., Tvory v piatokh tomakh, t. IV, Niu-York - Baltymor - Toronto 1938, s. 203-232. 